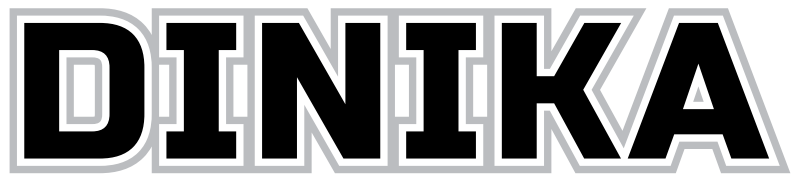

Academic Journal of Islamic Studies

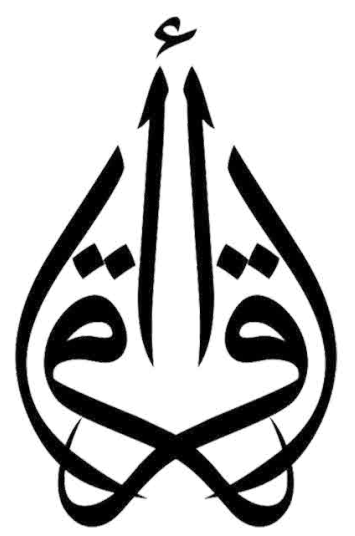


Volume 4, Number 3, September - December 2019 ISSN: 2503-42I 9 (p); 2503-4227 (e)

\section{DINIKA}

Academic Journal of Islamic Studies

\section{Table of Contents}

\section{Main Articles:}

Muslimab Beauty Veiling, Piety and Commodity in the New Indonesian

Public Sphere

Yuyun Sunesti

Competing Identity and Culture: The Formation of Forum Lingkar Pena and Komunitas Matapena in Indonesia

Nor Ismah

Ria Ricis and New Platform of Islamic Popular Culture

Wahyudi Akmaliah

\section{Articles:}

Perseteruan Memori Kolektif Kontestasi Islam dan Politik di

Tasikmalaya Pasca-Orde Baru

Amin Mudzakkir

Qital: Reinterpretasi Pendekatan Humanis

Ana Rahmawati, Azzah Nor Laila

The Characteristics of Philosophical Knowledge of The Qur'an and Prophetic Revelation According to Muni Laswad in His Book Islâm al-Falâsifa

Muhammad Makmun, Dessy Yanti Srie Budiningsih 


\title{
Ria Ricis and New Platform of Islamic Popular Culture
}

\section{Wahyudi Akmaliah}

Researcher at Research Center for Society and Culture, Indonesian Institute of Sciences (PMB-LIPI)

email:wahyudiakmaliah@gmail.com

\begin{abstract}
Not only change the landscape of popular culture, but the presence of social media also reshapes the structure and the agency. Nowadays, social media can turn ordinary people to celebrities. Using Instagram and YouTube, Ria Ricis has become a piety celebrity who shows her Islamic identity through Islamic performance by wearing the veil in a casual way and earns money from her uploaded videos in social media. Based on a case study of this figure, this paper raises questions related to Islamic popular culture in Indonesia: How does Indonesian define their public sphere currently amid the growth of social media usage? How does Indonesian Muslim respond to social media as a part of digital technology amidst Islamization in the post of an authoritarian regime? What is the possibility of tension for that young Indonesian Muslim as micro-celebrity while facing the three factors related, Islamic identities, enjoyment, and economic benefits? This paper argues that the new media platform has not only affected Indonesian Muslims' lifestyles, but also the way in which they negotiate Islamic values, secular life, and economic interest.
\end{abstract}

\section{Keywords:}

Ria Ricis, Social Media, Islamic Popular Culture, and Digital Economy

\section{Introduction}

Visiting many Indonesian provinces to understand his society is mandatory for Jokowi as the president. It is a kind of concern to his society whether they have voted for him or not in the national election. 
This coming to see directly his people often carried out by the president of Joko Widodo for several reasons such as observing the project infrastructure which he has planned during the election campaign in 2014, celebrating the biggest day, and meeting up with the local government, religious leader, prominent figure, and ordinary people. While attending to celebrate National Day of Children in Riau, he asked Rafi Fadila, the student of 36 public elementary schools (SDN 36) in the sixth class on the stage. Joko Widodo asked his dream. "I would like to ask Rafi, what are you going to be in the future?" Jokowi says. Instead of answering generally like other common students of elementary, mainly school such as being doctor, military, policeman, and teacher, his answer, however, spontaneously had made Joko Widodo's surprised and laughed. "I would like to be Youtuber sir", Rafi argues. Meanwhile, all of his friends were welcoming him warmly. The primary reason why he would like to be Youtuber is "if we have many subscribers (on our channel), it will earn money" (Anonim 2017)

Surely, having a dream for being Youtuber is still unusual for most of the Indonesian people, especially those who are an adult. However, this dream is very realistic for both children and adolescents. In regard to his answer, there are two reasons why being Youtuber currently is quite common for Indonesian young generation. Firstly, it is a different generation. Unlike their parents whose having a dream of job commonly and educated with the old system, such as learning from the teacher, understanding from the book, and asking from more old people, most of this generation are digital native where the presence of internet as their primary resources to understand many things. It is then supported by the possibility of material they can access easily and cheaper comparing with their parents 'life, such as a Smartphone, internet connection, and satellite infrastructure. Secondly, it is the growth of digital technology. The emergence of social media such as Facebook, Twitter, Instagram, Path, and 
YouTube, is not only changing our communication, but also our attitude in dealing with the public sphere. With an interaction communication, connected with other people which are borderless geographically and a possibility of sharing information in the real-time among other netizen are those factors that influence our public sphere. The position as both creator and receiver at the same time illustrates how they are equal structurally. The most different thing among netizen whether they are significant or not in social media is the level of their famousness and their persistence to be creating content in order to produce information to attract the plethora of viewers. If you are a celebrity or public figure but you are not using social media or having social media account but you could not maintain it, you can be an insignificant person. In contrast, by being an ordinary people can be a celebrity in social media if you can be both innovative and creative to create content as well as persistence to produce respectively.

In this new public sphere, the position of social media influencer is very important not only for the biggest technology company such as Google but also small companies in order to sell out their product with various benchmarks. Through Google aid and its certainly economic calculation, social media influencer can earn money from their video uploading. As much as people watching their video it is more social media influencer to obtain more money. In addition, a company can hire social media influencer to socialize their product as a part of the advertisement whether in YouTube, Instagram, Facebook, or Twitter. This is a kind of 'structure participation' as a new platform on how young generation perceives themselves and their world in the wave of digital technology convergence. Because of this trend, many social media influencers have emerged in Indonesia that have played the biggest role to influence netizen through their social media account while they are not only can survive but also being a richer people. Those social media influencers as micro-celebrities are, for instance, Raditya Dika, Ria Ricis, Young Lex, 
Auwakarin, and others. Therefore, Rafi's dream of being Youtuber is a realistic idea.

Because of the majority of Indonesian religion is Muslim, the growth of digital technology is definitely has impacted most of their everyday life. This argument is based on two facts. Firstly, Indonesia is the world's sixth largest internet user after China, US, India, Brasil, and Japan as well as. This position is not only as of the number but also contribute in order to create communication among them. Secondly, in the level of Islamic preaching, through social media, the internet as the medium for many Islamic groups to propose their ideologies by making "Islamic content version" (Nilan, 2006; Ali, 2012; Slama 2017). In regard of Islam and Indonesian context, especially Islamic Popular culture, many scholars have discussed in the variety of form and specific issue, covering television program and movies (Amrih 2017; Heryanto 2014; Barendregt 2012; Imanjaya 2006; Arp and Van Helen, 2006; Subianto 2011; Van Heeren 2012; Rahmani, 2016; Barendgret and van Santeen 2002; Weintraub 2008, 2010); print media and literature (Brenner 1999, 2011; Hefner 1997; Hellwig 2011; Krier 2011; Rani 2012; Kailani, 2012) and clothing (Brenner 1996; Smith-Hefner 2007; Saluz 2007; Nisa 2012).

However, discussing the impact of digital technology in Muslim society in Indonesia backdrop is still rare, especially by focusing on social media and the emergence of micro-celebrities intertwining with the digital economy. In fact, Heryanto (2014: 2) has reminded the significant of this study in the midst of "recent change to the mediascape in Indonesia" that "has become glaringly evident how new media has intervened and reshaped our social lives across the globe at many levels". By proposing Ria Ricis, one of Indonesian young Muslim Youtubers as the case study, this article examines Islamic popular culture in Indonesia amid digital technology by raising three questions; How does Indonesian define their public sphere currently? How does Indonesian Muslim respond to social 
media as a part of digital technology in the midst of Islamization in the post of an authoritarian regime? What is the possibility of tension for that young Indonesian Muslim as micro-celebrity while facing three factors related, mainly Islamic identities, pleasure, and economic benefits? This paper argues that the new media platform has not only affected Indonesian Muslims' lifestyles, but also the way in which they negotiate notions of Islamic values, secular life, and economic interest.

\section{Internet, Social Media, and New Public Space}

Historically, compared to the West that had emerged in the 1980s, the emergence of the internet in Asia, including Indonesia was in the 1990s. It was to be "the media-democracy" in the midst of the authoritarian regime's censorship on the old media such as television, mass media, and radio. Specifically, there are two reasons why it was as "mode of communication" for insisting democracy. Firstly, both Indonesian scholars and activists created the networks in the national and international level within the underground contact in order to avoid the state's surveillance. Secondly, the internet with both e-mail newsgroup and websites worked as alternative new resources while the authoritarian regime had been controlling the old media strongly (Hill and Sen 2005: 10). One of these new alternative resources was provided from George Junus Aditjondro, the Indonesian scholar, teaching as a professor of sociology at the Newcastle University, Australia (Merlyna Lim 2006). This new alternative information then copied and spread in and out of the campus as well as an energy that motivated them to criticize and to step down the Suharto regime from his power.

In the post of the authoritarian regime signaled by the Suharto presidency stepped down on May 21, 1998, Indonesian faced the transition democracy. It steeply changed the Indonesian system from the centralization power to be decentralization while the local governments had an authority 
to manage and to lead their provinces. Region autonomy (Otonomi Daerah) was a part of this product. However, this change had given two impacts. One hand, the transition was an opportunity for the old oligarchy to reorganize their power in the local and the national level (Robinson and Hadiz 2004). Meanwhile, on the other hand, it strengthened the previous Islamic conservative groups which had been violated during the Suharto regime emerged in the public sphere. Although in some extends, this condition gave a possibility for the local governments to modernize and support their provinces through good policies in order to make beneficial for their people economically and socially. As the public contestation, the post of the authoritarian regime was as momentum to propose Islamic group ideology. In the context of the internet, Laskar Jihad was the most advanced Indonesian mass organization practiced in order to hire their members as well as to mobilize their Islamic identities as a counterbalance from the (Christian) west media. Moreover, many west media distorted an image of Islam, especially in the midst of Maluku Conflict which began in January 1999. The Islamic media as the representation of the Islamic identity of Indonesian Muslim as well as significant force showed by the establishment of an official website on Laskar Jihad online (Lim 2005: 14-15)

The improvement of web technology then raises the group of Indonesian blogger in various contents through both writings and pictures, such as in www.blogger.com, www.wordpress.com, and www. multiply.com. With those platforms, they created many contents as a part of their daily life diary and alternative information in the midst of printed media locally and nationally that could not criticize sharply and analysis deeply on some issues. In addition, Friendster as the beginning of social network had established to connect people around the world with the feature limitation. The development of Smartphone by the emergence of Google as the huge browsing has created the two systems, mainly Android 
and Apple with its own path. In the same time, since 2009 Facebook as the new face of social networks which was more interactive opened to the public internationally, in which every people can open their own account as the user. The variety of new platform social media development such as Twitter, Instagram, and Path, become a new public sphere nationally and internationally. In the context of Indonesia as same as other countries, social media is not only used as social networks but also a part of the social movement. It was reflected in the two cases as a common example for those studying social media activism, mainly Coin for Prita and Cicak versus Buaya (Lim 2013).

The most significant of social media usage can be seen clearly by explaining the figure of the internet usage for Indonesian as well as the user of social media that often higher every year respectively. According to the Indonesian Internet Service Providers Association' survey in the period of 2017, there are more of almost half of Indonesian population that have been connected to the internet, mainly from all of the population (266,2 million people), about the 143, 26 million of them are internet users. Those figures accessed the internet from the four different technological devices. Statistically, there are 44, $26 \%$ accessing the internet through both smartphone and tablet, while only 4, $49 \%$ using a computer or laptop. Meanwhile, there are 39, $28 \%$ using both devices. Lastly, there are 12, 07 $\%$ of Indonesian using others. Geographically, the majority of an internet user is in the urban area with a percentage of $72,41 \%$. Meanwhile, the rural-urban area has reached $49,49 \%$ and the rural with the percentage of $48,25 \%$. Comparing to gender, the male is more dominant with the $51,43 \%$, and female is a little bit lower with the percentage of $48,57 \%$.

In regard to social media users, Facebook is the highest of Indonesian visitors (54\%), following by Instagram (15\%) and Youtube (11\%) as the second and the third rank. Both Twitter and Google Plus sharing slightly the same percentage ( $6 \%$ and $5,5 \%$ ), it is then followed by Linked In 
as the smallest percentage comparing others social media as it has been mentioned (0,6 \%). Sri Widowati, Country Director Facebook Indonesia strengthened the Facebook users every year by showing information that in 2016 there were 88 million of Facebook users. This trend increase is more progress around 6 million of people comparing in 2015, was only 82 million Facebook users (Anonim 2016 2017). For Instagram, Indonesian is the first rank user in the Asia Pacific region, specifically from the 700 of million Instagram active users in the world, 45 of million from this figure coming from Indonesian (Anonim 2017 2017b). For Youtube, Tony Keusgen, Managing Director Google Indonesia, explains the long duration of watching on the period of 2016 in Indonesia which facing the dramatically increase up to $155 \%$ that consist of 100 of million people was using it. He predicted that in 2017, there will be around 150 million people following by the increasing of video consuming for about sevenfold in 2020 (Anonim 2017, 2017b).

At least, there are two reasons why the development of internet users is significant in Indonesia. Firstly, it is the telecommunication infrastructure improvement and democratization of smartphone access. As a part of continuity to build a tower of Base Transceiver Station during the Suharto regime up to the current government, many Indonesian provinces can access an internet connection. Meanwhile, the present of android system Smartphone from China with affordable prices attract Indonesian to consume it. Secondly, it is a communal culture and oral tradition. Social media and its feature as social networks are suitable with Indonesian character that often making interaction one and other such as talking as a part of leisure time, visiting their families and friends, grouping with their same interest and passion (Akmaliah 2017). In this sense, some of Indonesian could not differentiate whether the private or public area as west culture strictly divided it. Because of this, social media become a new public space where people can propose anything 
they want. During the biggest day of Islam, the function of social media is a part of Islamic gathering. In the period of the local and national election, social media is as a tool of field contestation in order to influence voters. Both Presidential (2014) and Jakarta Election (2016-2017) are two cases on how social media as a critical point to perceive an image of those candidates negatively and positively so voters hopefully either choose "us" or "them". In addition, the internet, social media, and its new app also give a possibility for small and big business traders to sell their products in many features and mediums. One of those mediums is using the service of micro-celebrities to endorse their products through social media.

\section{Social Media, Islamic Piety, and Pop Culture}

This part will be discussing the two issues, mainly Islamic preaching and the change of mediation form as well as Ria Ricis as the new platform of Islamic popular culture by discussing her position as both young Muslimah and micro-celebrities amid digital economy.

\section{Islamic Preaching and Netizen Piety}

Many scholars have concerned how the internet contribution as a part of religious expression as well as new challenges religious authority (Barker 2005; Barendregt 2009). In the context of Indonesian, the internet becomes a tool for many Indonesian Muslim, especially searching for online fatwa and seeking religious advice through the biggest browsing of Google (Hosen 2008). The presence of social media is also used by many Islamic preachers and Islamic institutions as a medium to deliver Islamic values and problem-solving in accordance with the sources of Quran and Hadiths. The form of this kind of social media is the messenger services, such as Blackberry Messenger, WhatsApp, Line, and Telegram, where one of these applications feature is creating a group of the invited member. Not only accessing easily for the members to ask, consult, and discuss, this 
online mediation can be a way for the preachers to deliver Islamic messages vastly in order to answer those many problems which are questioned by them. Through the two-way communication give a possibility for their followers to engage in personal conversation, mainly consulting many issues such as the relationship of their marriage, the principle of five prayers, and other social problems of life (Slama 2017: 98-99).

In contrast to those devices, although they have also private messengers as the previous social media, Facebook, Instagram, Twitter, and Youtube can obtain audience largely through the followers and subscribers' system without limitation, by emphasizing the public consumption openly. In order to create Islamic piety in accordance with Quran and Hadits, many Muslim consists of Islamic preachers, ordinary people, community, and institution; propose their Islamic values and its interpretations within these devices as a form of preaching. To gain popularity in order to attract followers, preachers' capability and its figure create his/her persona, especially their abilities to categorize specific audiences, as well as a kind of Islamic ideologies, proposed to influence Indonesian netizen. For instance, choosing related issues as his main topics, Felix Siauw has targeted young Indonesian Muslim for being his field of preaching; Awy Qowalun is consistently teaching Islamic values with more moderate perspective for Muslim largely. Both of these preachers are employing their twitter account to perceive their Islamic teaching (Nadzir, 2017). Through the tagline of Hijrah as the main issues within Islamic values, both Salman AlJugjawy and Hanan Attaki adopting Instagram for preaching in different way; while Salam is only sharing some pictures containing good messages on how to become good Muslim as well as selling his cloth product, Hasan explains social problems facing every human and proposing Allah and its regulation as the main helper to solve their problems by practicing popular culture form through the video and its music illustration. 
Above the explanation illustrates continuity and change on the internet contribution as a religious expression to create and to strengthen their belief and piety. Online mediation as a form of preaching is following with the change and improvement of digital technology itself. More personally and group, many Islamic preachers are using messenger services within social media in order to keep in touch with their followers. Furthermore, for the large audience and with the more open system, some preachers use other current social media platforms. Without relying on the figure, at the level of institution, Yufid TV is the most of the Islamic channel on YouTube with professional management as the huge subscribers and viewers in Indonesia. We can see this professionalism through the quality of the content. Ibnu Nadzir (2017) explains that if we see slightly the Yufid TV's videos is the same as other videos containing Islamic preaching. However, the most significant thing that Yufid TV is different comparing other Islamic channel preaching is the content representation that adjusting the rule of online platform generally on Youtube; long video's duration only 10 minutes, containing with visually attractive, maintaining subscribers and enlarging viewers by uploading one video and more every day.

\section{Enjoyment and Digital Economy}

Not only challenging the old media and stability of the social structure, the internet, and social media with the democratization of participation structure have questioned the definition of significant people. Through the hard working by creating both innovative and creative videos, pictures, and writings respectively, interacting communication intensively, ordinary people with various backgrounds can achieve their popularities as same as celebrities. Referring to Theresa M. Senft's theory (Senft 2008: 25), it is well-known as micro-celebrity which is "understood as a new style of online performance that involves people 'amping up' their popularity 
over the Web using technologies like video, blogs, and social networking sites". Specifically, (Marwick and Boyd 2010: 121) illustrate micro-celebrity that 'implies that all individuals have an audience that they can strategically maintain through ongoing communication and interaction'. In the context of Indonesia, many ordinary people are reborn as micro-celebrities in social media. However, among those of micro-celebrities, only Ria Ricis is representing a voice of Indonesian young Muslim Islam. At a glimpse, it is indicated by the two things, saying Assalamualaikum when she started her video as well as covering herself by the veil. Although there are some of the YouTubers are representing Islam as same as her, but their followers are not so much as Ricis. Indeed, she claims that what she produces on videos in both social media (Instagram and YouTube) is a part of her way of Islamic preaching softly.

Ria Ricis is not the real name, while her name is Ria Yunita. RICIS is is an acronym that she made. It is Rla Cantik dan Manis Nan Baike Hati Kaya Akan Kejujuran (Ria is both beautiful and sweet with fully kindness and honesty). For her, using Instagram is not something new. She began using it since she was at Senior High School (SMK) and achieving for about 7 thousand of followers. The aim of making both meme and parody videos was only for making her pleasure. When she pursued her study at the university, her Instagram account suddenly had stopped due to being hacked. Because of this, she was very sad for a week and made her stressful. She steeply rose up and started creating a new Instagram account again. Under her new account@ria_ricis1795, she uploaded both meme and funny video as previously. Coinciding with the Mother day, 22 December, she created the video of "Mama, I love you" (Mama, aku sayang mama). Unlike another mother day that celebrates it commonly by saying on the beautiful words how the mother has sacrificed herself to her children, Ria Ricis with the comical face is acting the two position in the same time between herself and her mother. Acting both different positions 
and how she asked and answered spontaneously attracting people to laugh and, on another hand, to realize that the scene in this video had ever been done for them also in reality. Starting from this video, her followers have enlarged and bigger every day (Anonim 2015 2017).

Dealing with Islamic preaching softly in the term of Ria Ricis's style, at least, there are five videos that she created and has been responded warmly by Indonesian netizen as some of the examples on both YouTube and Instagram. Firstly, it is an Islamic manner how goes to the toilet. Instead of employing the right foot to enter the toilet and both of foot (right and left together) like Indonesian ghost walking by a jump (pocong), she suggests using left foot. Secondly, being a single till to be halal (get marriage). Many of her videos are explaining how difficulties being single. These videos surely based on her ages experiences that are having boyfriend and girlfriend commonly. However, although creating many parodies and funniest videos of being single in varieties form, she and herself suggest to netizen to not thinking how to make a relationship without marriage. Indeed, she asserts that it is better for being single until she gets marriage rather than having boyfriends or girlfriends while they will face on/off breaking the relationship. Thirdly, it is Islamic manner how to pray before eating. The presence of the Smartphone with the convergence of the internet and social media encourages people to take a picture for selfish. One of the areas that often taking for it is in the restaurant. Through her short video, Ria Ricis reminds netizen to pray before eating, instead of taking a picture for themselves.

Fourthly, being beauty without changing Allah's creation. The current mode of being a beauty by cutting off an eyebrow and changing it through printed tattoos are common. Through her video, Ricis reminds for women to not doing it. She then suggests them to employ pencil to make them more beautiful as the Quran already teach them (Anonim 2015 2017a). Fifthly, the mandatory for five times praying. Playing an act both 
two actors at the same time, Ricis softly reminds netizen to not forget and to not leave praying in every situation due to nobody knows when death will be coming to us. Meanwhile, many Muslim are not preparing yet when it is truly coming to them. Not only citing the verses of Quran, but Ria Ricis also put the Hadiths covering the Prophet of Muhammad's words and his best exemplary within the caption explanation below the video.

Because of her parody, funny and comical short videos in accordance with the sense of young Indonesian generation as well as Islamic preaching softly, many Indonesian netizen follow her respectively. Many people assumed including me previously that Ria Ricis's popularity gained due to her big sister as a celebrity, Oki Setiana Dewi. She then just rides the wave of her big sister popularity. However, if we close observing her both consistent and commitment in order to produce video nicely and creatively has enlarged her followers and subscribers whether on Instagram or YouTube channel. Indeed, she is the main supporter to raise her biggest sister to socialize in social media widely. Referring to (Khamis, Ang, and Welling 2016: 7) on the rise of micro-celebrity, what Ricis has been achieved is a part of "demotic turn", mainly "ordinary people seek and find fame through practices of micro-celebrity" by redistributing "cultural power in both media and marketing". Furthermore, they describe, "micro-celebrity points to the growing agency, enterprise and business acumen of everyday media users". The concept of demotic turn is borrowed from Turner when he illustrates the phenomena of ordinary people joining the American television reality show such as Big Brother, American Idol, and Survivor. This term describes the two fundamental things; the changing of media by accepting ordinary people's accessing large publicity and their willingness to aim for being famous. Specifically, (Turner 2006: 156) points out it deeply, "given what appears to be our culture's appetite for consuming celebrity and the scale of the demand for new stories, gossip and pictures the celebrity-media industries generate, 
the accelerated commodity life cycle of the celetoid has emerged as an effective industrial solution to the problem of satisfying demand".

Not only for a digital company such as Google Ad sense, is a microcelebrities fundamental factor for small and big companies to sell their products. By uploading videos on YouTube channel, micro-celebrities can monetize it in accordance with Google's economic calculation advertisement. Through Instagram, micro-celebrities could be ambassador to endorse every various product questioned by the company. In the case of Ria Ricis, she started using Youtube on January 15th, 2016. For two years, she has produced and uploaded 145 videos (March 15, 2016- September 30,2017 ) with total viewers, $201,877,704$ and $1,755,654$ of subscribers. The highest viewer of her video is watched by 7.129.037, in which the topic of her was "RAINBOW SQUISHY TAG + GUNTING SQUISHY?! sayang banget...”. Meanwhile, “The BALLOON CHALLENGE - RIO ARDHILLAH TERSIKSA?” is the smallest of her video which was uploading on December 4, 2016, particularly she just achieved 247.010 of viewers. By using socialblade.com, I obtain information that for one video she is estimated earnings around $\$ 293-\$ 6.300$ (see Figure 1). Specifically, she estimated monthly earnings, around $\$ 7.600$ - $\$ 12.200$, while per-a year, estimated yearly earnings, around $\$ 91.5000$ - $\$ 1.500 .000$ (see Figure 2). This two statics information explain Ria Ricis's achievement deeply, especially data from September 19th, 2017- October 2nd, 2017 as the example. 
Figure 1. Ricis's Video

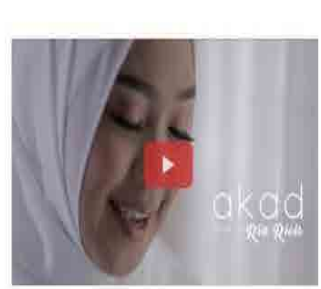

\begin{tabular}{|c|c|c|c|c|}
\hline $\begin{array}{c}\text { A }= \\
\text { TOTAL GRADE }\end{array}$ & $\begin{array}{l}\text { 2,191st } \\
\text { suesCRBBERRANK }\end{array}$ & \multicolumn{2}{|c|}{$\begin{array}{l}7,258 \text { th } \\
\text { vibEO VIEW RANK }\end{array}$} & $\begin{array}{l}1,449 \text { th } \\
\text { SOCIAL BLADERANK }\end{array}$ \\
\hline \multicolumn{2}{|c|}{$\begin{array}{l}30,496,200.25 .6: 5 \\
\text { VIEWS FOR THELAST } 30 \text { DAVS }\end{array}$} & \multicolumn{3}{|c|}{$\begin{array}{c}191,301=9,69 \\
\text { SUBSCRIBESFOR THE LAST } 30 \text { DAYS }\end{array}$} \\
\hline $\begin{array}{l}\text { None } \\
\text { NETWORK/CI.AIMED BY }\end{array}$ & $\begin{aligned} \$ 7 . \\
\text { ESTMATE }\end{aligned}$ & $2 \mathrm{~K}$ & & $\begin{array}{l}.5 K-\$ 1.5 \mathrm{M} \\
\text { ED YEARLY EARNASGS }\end{array}$ \\
\hline
\end{tabular}

Figure 2. Ricis's Earnings

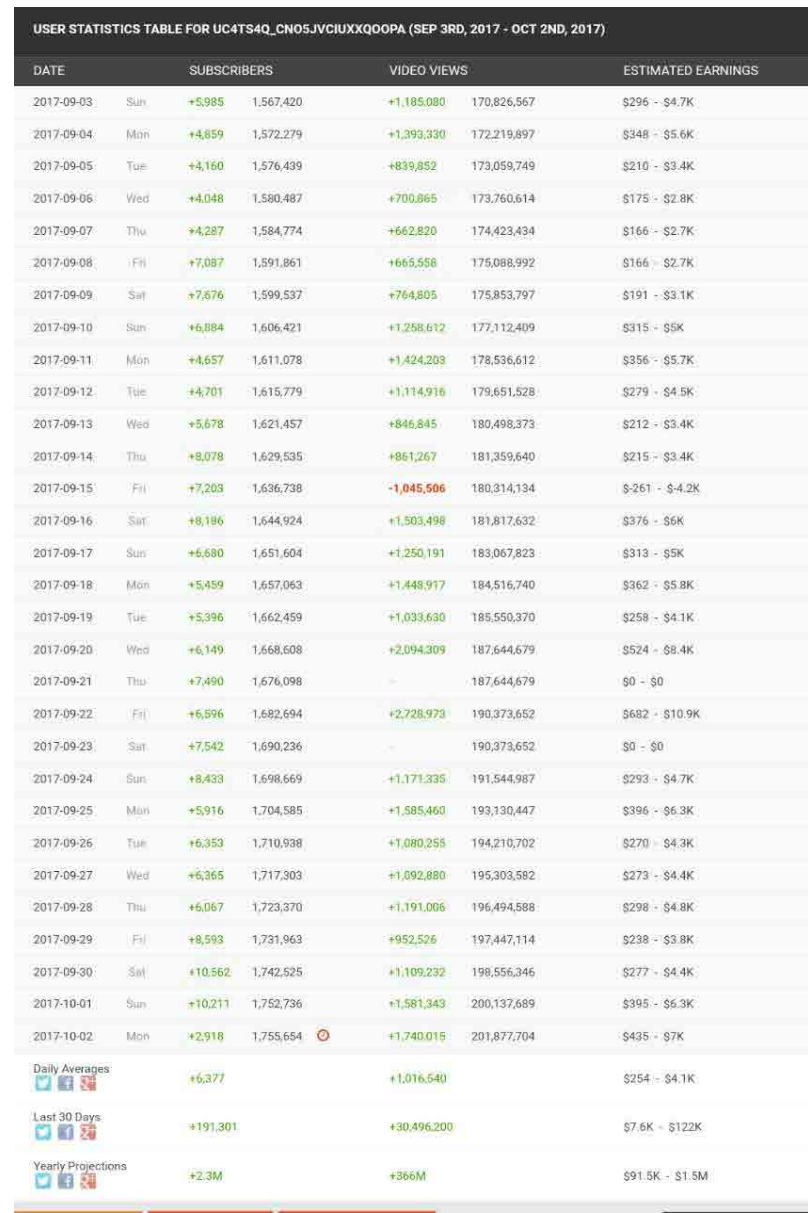

DINIKA, Volume 4, Number 3, September - December 2019 
For Instagram, Ria Ricis has 7,414, 327 followers, 1,436, 793 likes, 1,020 post, and 24,008 comments. According to influencermarketinghub. com that I employ to analysis, Ricis's Instagram account can estimate earning money around $\$ 11,122-\$ 18,536$ per post. In fact, she just asks for the endorsement of every product around Rp.4-5 million rupiah, while in one day she can post around 2-4 endorsement products. If she posts only 3 endorsements per day, it is estimated will earn money around Rp. 144,000,000, or one hundred and four million rupiah every month. Mostly, companies who are asking her endorsements are working on online shopping (Anonim 2016, 2017b). In order to keep Ria Ricis's image, many of endorsement requests have to adjust with her performance as a young Muslim. Therefore, many endorsements she uses on her Instagram are related with Islamic identity and its principles such as veil, mukena (such kind of white cloak covering a woman's head and body worn at prayer), shoes, perfume, food, wallet, cosmetic, and medical skin. Relating to Islamic identity, when she endorses the veil, she creates a paragraph of wisdom words as a form of reminder to the biggest creator, mainly Allah who determines every activity we do on her Instagram account on July 25 , $2017 .{ }^{1}$

"There is no perfect man. As human, we sometimes feel so perfect that make us forgeting ourselves that what we all have done it must be true. Because of this, Allah then intervenes by giving both the trials and warnings to prove that there is perpect man. Man is the place of wrong and sinful. You can blaspheme others if you NEVER WRONG. Therefore, you should be humble and always grateful as well as neither giving up nor complaining. Because complaining is

1 "Manusia tidak ada yg sempurna. Saking merasa sempurnanya kita kadang sampai lupa diri bahwa apa yg kita lakukan semua pasti benar. Maka dari itu Allah turun tangan utk memberikan cobaan dan peringatan bahwa tidak ada manusia yg sempurna. Manusia tempatnya salah dan berdosa. Silahkan menghujat yg lain jika kalian TIDAK PERNAH BERBUAT SALAH. Tetap rendah hati dan selalu bersyukur, jangan pernah menyerah apalagi mengeluh. Karena mengeluh hanya dimiliki oleh orang2 yg tdk pernah bersyukur. Apalagi jomblo kalau ngeliat yg laen udah naik pelaminan, kita blm nemu yg cocok. Sabar ya mbo". 
only for those who are never to be grateful. Moreover, those who are singles are often not to be grateful while many of their friends are getting to the wedding. Be patient, we have not met yet for the right person. Hijab by@ricisbykhayra"

Figure 3. Ricis's Estimated Earnings Per Post

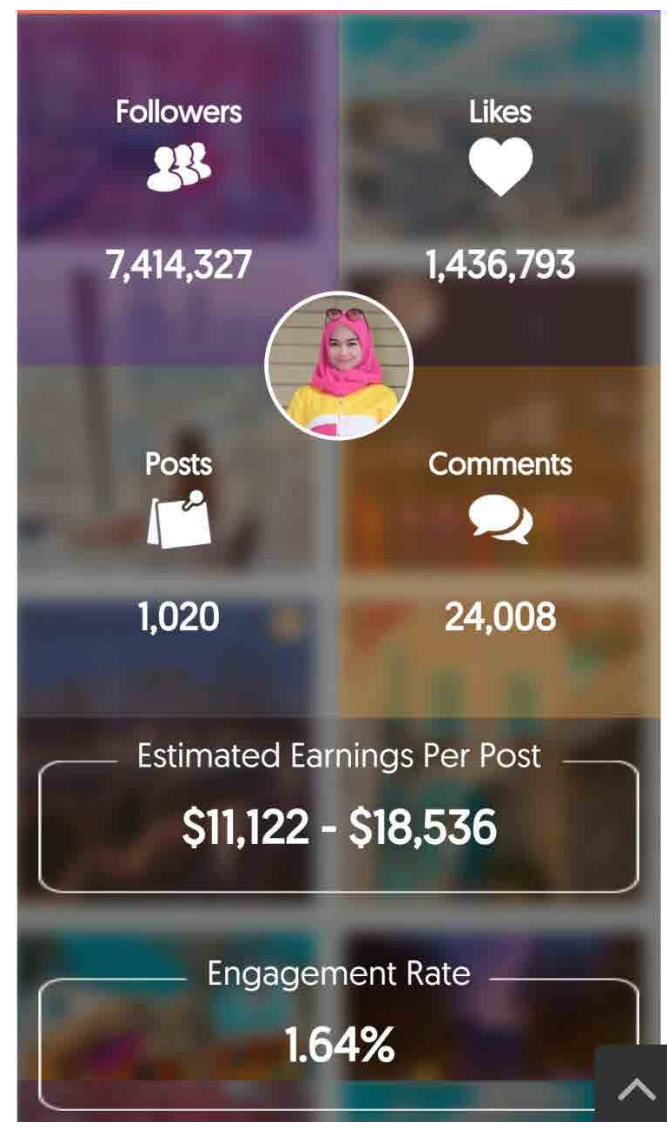

\section{Conclusion}

Above explanation provides me insightful information that social media is not only Islamic preaching mediation between preachers and their followers as it has been discussed by the previous scholar as well as a part of the medium performance to show Islamic piety. The development of digital technology, coinciding by the growth of internet users in Indonesia, 
social media is as a new public sphere. In the midst of Islamization, it is useful for the two things, mainly the field of Islamic preaching while social media as online mediation as well as it is the enmeshment between Islamic identity, pleasure, as well as economic interest. By putting the Ria Ricis case as one of the young Muslim representations, Islamic popular culture is hard to categorize as the only process of Islamization in the post of the authoritarian regime as many scholars thought on their works dealing with Islamic pop culture. It is not also as an object of commercialization as it has been discussed by some scholars. Furthermore, it is an opportunity to strengthen their Islamic identity amidst digital technology growth that gives a possibility to gain economic benefit. Surely, within this condition, both tension and contestation will be happening for Indonesian Muslim societies, while on the other, in some cases, they can negotiate and support one and other.

\section{References}

Akmaliah, Wahyudi. 2017. "Menguatkan Keyakinan, Menolak Kenyataan: Ketegangan Personal dan Menguatnya Populisme Islam di Indonesia." Jurnal Maarif 12 (1).

Amrih, Widodo. 2017. "Writing for God: Piety and Consumption in Popular Islam.” Insideindonesia.Org. 2017. http://www.insideindonesia. org/writing-for-god.

Barendregt, Bart. 2009. "Mobile Religiosity in Indonesia: Mobilized Islam, Islamized Mobility and the Potential of Islamic Techno Nationalism." In Living the Information Society in Asia, edited by Erwin Alampay, 73-92. Singapore: Institute of Southeast Asian Studies. 
Barendregt, Bart. 2012. "Diverse Digital Worlds.” In Digital Anthropology, edited by Heather A. Horst and Daniel Miller, 203-24. London: Berg.

Barker, Eileen. 2005. "Crossing Boundary: New Challenges to Religious Authority and Control as a Consequence of Access to the Internet.” In Religion and Cyberspace, edited by Morten Højsgaard and Margit Warburg, 67-85. London: Routledge.

Heryanto, Ariel. 2014. Identity and Pleasure: The Politics of Indonesian Screen Cultur. Singapore: NUS Press.

Hill, David T., and Khrisna Sen. 2005. The Internet in Indonesia's New Democracy. London: Routledge.

Hosen, Nadirsyah. 2008. "Online Fatwa in Indonesia: From Fatwa Shopping to Googling a Kiai." in Expressing Islam: Religious Life and Politics in Indonesia, edited by Greg Fealy and Sally White, 159-73. Singapore: Institute of Southeast Asian Studies.

Howell, Julia Day. 2008. "Modulations of Active Piety: Professors and Televangelists as Promoters of Indonesian 'Sufisme."' In Expressing Islam: Religious Life and Politics in Indonesia, edited by Greg Fealy and Sally White, 40-62. Singapore: Institute of Southeast Asian Studies.

Khamis, Susie, Lawrence Ang, and Raymond Welling. 2016. "Selfbranding, 'Micro-Celebrity' and the Rise of Social Media Influencers." Celebrity Studies. 2016.

Lim, M. 2013. "Many Clicks but Little Sticks: Social Media Activism In Indonesia." Journal of Contemporary Asia 43 (4): 636-57.

Lim, Merlyna. 2005. "Archipelago Online: The Internet and Political Activism in Indonesia." University of Twente, The Netherlands.

Lim, Merlyna. 2006. "Cyber-Urban Activism and the Political Change in Indonesia." Eastbound 1 (1): 1-19.

Marwick, A.E., and D. Boyd. 2010. "I Tweet Honestly, I Tweet Passionately: Twitter Users, Context Collapse, and the Imagined Audience." New Media \& Society 13 (1): 114-33. 
Robinson, Richard, and Vedi R. Hadiz. 2004. Reorganising Power in Indonesia: The Politics of Oligarchy in an Age of Markets. London: Routledge.

Senft, T.M. 2008. Camgirls: Celebrity and Community in the Age of Social Networks. New York: Peter Lang.

Slama, Martin. 2017. "A Subtle Economy of Time: Social Media and the Transformation of Indonesia's Islamic Preacher Economy." Economic Anthropology 4: 94-106.

Turner, G. 2006. “The Mass Production of Celebrity: 'Celetoids', Reality TV and the "Demotic Turn"." International Journal of Cultural Studies 9 (2): 153-65.

\section{Website Sources}

Anonymous. 2017a. "5 Dakwah Unik Ala Ria Ricis yang Kocak Habis." Selebupdate.Com. 2017. http://www.selebupdate.com/dakwahria-ricis/13377.

Anonymous. 2017a. "Di Depan Jokowi Anak SD Ini Mengaku BercitaCita Jadi Youtuber.” Detiknews. 2017. https://news.detik.com/ berita/d-3570033/di-depan-jokowi-anak-sd-ini-mengaku-bercitacita-jadi-youtuber.

Anonymous. 2017a. "Jumlah Pengguna Facebook Terus Bertambah.” Kompas.com. 2017. http://tekno.kompas.com/ $\mathrm{read} / 2016 / 10 / 20 / 17062397 / j u m l a h . p e n g g u n a . f a c e b o o k$. di.indonesia.terus.bertambah.

Anonymous. 2017b. "Google: Durasi Tonton Dan Jumlah Konten Youtube Indonesia Tumbuh Pesat.” Kumparan. 2017. https:// kumparan.com/jofie-yordan/google-durasi-tonton-dan-jumlahkonten-youtube-indonesia-tumbuh-pesat.

Anonymous. 2017b. "Mengenal Lebih Dekat Ratu Instagram.” Dream. co.id. 2017. https://www.dream.co.id/showbiz/mengenal-lebihdekat-ratu-instagram-151029h.html. 
Anonymous. 2017b. "Terungkap Tarif Endorse Ria Ricis Ini Bikin Kamu Melongo.” Tribunnews. 2017. http://style.tribunnews. com/2016/10/30/terungkap-tarif-endorse-ria-ricis-ini-bikinkamu-melongo.

Anonymous. 2017c. "Instagram Punya 45 Juta Pengguna Aktif di Indonesia." Kumparan. 2017. https://kumparan.com/adityapanji/instagram-punya-45-juta-pengguna-aktif-di-indonesia.

Asosiasi Penyelenggara Jasa Internet Indonesia (APJII). 2016. Penetrasi dan Prilaku Pengguna Internet di Indonesia: Survei 2016. APJII. 